\begin{tabular}{|c|c|c|c|c|c|c|}
\hline \multirow{4}{*}{ Impact Factor: } & ISRA (India) & $=3.117$ & SIS (USA) & $=0.912$ & ICV (Poland) & $=6.630$ \\
\hline & ISI (Dubai, UAE & $=\mathbf{0 . 8 2 9}$ & РИНЦ (Russia & $=0.156$ & PIF (India) & $=1.940$ \\
\hline & GIF (Australia) & $=0.564$ & ESJI (KZ) & $=8.716$ & IBI (India) & $=4.260$ \\
\hline & JIF & $=1.500$ & SJIF (Morocco & $=5.667$ & OAJI (USA) & $=0.350$ \\
\hline
\end{tabular}

\begin{tabular}{|c|c|}
\hline $\begin{array}{l}\text { SOI: } \underline{1.1 / \mathrm{T}} \\
\text { International Sc} \\
\text { Theoretical } \mathbb{\&}\end{array}$ & $\begin{array}{l}\frac{\mathrm{AS}}{\mathrm{D}} \text { DOI: } \frac{10.15863 / \mathrm{TAS}}{\text { cientific Journal }} \\
\text { Applied Science }\end{array}$ \\
\hline p-ISSN: 2308-4944 (print) & e-ISSN: 2409-0085 (online) \\
\hline Year: 2019 & Volume: 70 \\
\hline Published: 28.02 .2019 & http://T-Science.org \\
\hline
\end{tabular}

SECTION 31.Economic research, finance, innovation, risk management.
QR - Issue

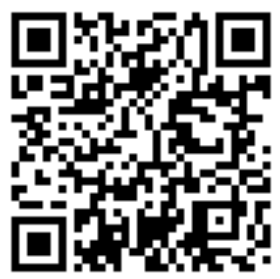

QR - Article

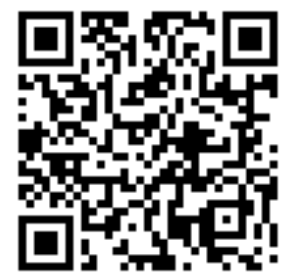

Guzal Abdazovna Adilova $\mathrm{PhD}$, doctorate of Research Institute of Agricultural Economics, Tashkent, Republic of Uzbekistan

\title{
SCIENTIFIC AND METHODOLOGICAL FOUNDATIONS OF THE FORMATION OF THE DIGITAL ECONOMY SYSTEM IN AGRICULTURE OF UZBEKISTAN
}

Abstract: This article outlines the key aspects of using the neural network system in the development of the agricultural economy in the country, increasing the quantity and quality of the crop, and facilitating future agricultural work. The author identified the main directions of creation and implementation of innovations in agriculture. Also illustrated is the structure of work performed in "smart farming".

Key words: neuron, technology, innovation, agriculture, quality.

Language: English

Citation: Adilova, G. A. (2019). Scientific and methodological foundations of the formation of the digital economy system in agriculture of Uzbekistan. ISJ Theoretical \& Applied Science, 02 (70), 274-277.

Soi: http://s-o-i.org/1.1/TAS-02-70-26 Doi: crossef https://dx.doi.org/10.15863/TAS.2019.02.70.26

\section{Introduction}

Among the many factors that contribute to the economic development of the country, solving the problems of social protection of the population and the strengthening of social stability are the important directions of food security. Food security is largely dependent on the level of development of agriculture, quantitative indicators of production, processing conditions, quality of the products, storage, agrotechnological processes, as well as availability of products in the markets.

\section{Literature review}

According to this research, theoreticalmethodological foundations of socio-economic development of agriculture are presented by foreign scientists L.Tsfu, Ts.Fan, L.Chjou, LV.Agarkova, I.B.Buzdalov, I.Sandu, I.G.Ushachev, the problems of the market of fruit and vegetable and grape products were analyzed by foreign scientists such as N.Popov, A.Khudratov on the role of Uzbek scientists in the development of agriculture in improving the well-being of the population on improving the economic relations in the development of grain growing in the Republic of Uzbekistan, G. Kudratov, the problems of agricultural development and their practical and theoretical significance. M.Juraev, R.H.Husanov, Abduganiev A.[2], Hasanov
Sh. T.[3], Ahmedov A. K. [4], R. Hakimov et al. [5], A. B. Barsky [6], D.S. Kurnikov, S.A. Petrov [7], Yuldoshev N. et al.[8], Tursunov, B [9], Yezhov A.A.[10] increasing the efficiency of production at the agricultural enterprises of various forms of ownership, A.H.Burhonovs research. The above mentioned scientific works will be a major factor in theoretical and practical scientific study of the effectiveness of the agricultural product market in the conditions of modernization of the economy, contributing to the agrarian-economic science. Despite the fact that in the process of liberalization of the economy of the Republic of Uzbekistan reforms were carried out on practical aspects of organizing, managing and increasing the effectiveness of agricultural economy, the research was not enough insufficient study of the existing problems, and the basis for conducting research on this issue.

\section{Analysis and results}

The development of the agricultural economy in our country, the reforms carried out to increase the volume and quality of production are yielding its effect. As a result of the measures taken to diversify the agricultural production reform, improve land reclamation, introduce modern high-tech technologies and strengthen the material and technical base of farms, the gross agricultural output 


\begin{tabular}{|c|c|c|c|c|c|c|}
\hline \multirow{4}{*}{ Impact Factor: } & ISRA (India) & $=3.117$ & SIS (USA) & $=0.912$ & ICV (Poland) & $=6.630$ \\
\hline & ISI (Dubai, UAE & $=0.829$ & РИНЦ (Russia & $=0.156$ & PIF (India) & $=1.940$ \\
\hline & GIF (Australia) & $=0.564$ & ESJI (KZ) & $=8.716$ & IBI (India) & $=4.260$ \\
\hline & JIF & $=1.500$ & SJIF (Morocco & $=5.667$ & OAJI (USA) & $=0.350$ \\
\hline
\end{tabular}

will reach 69504.2 billion soums by 2017. soum or $102.0 \%$ to the corresponding period of 2016. In particular, agriculture and livestock, hunting and services provided in these sectors - 68906.7 billion soums. $(101.9 \%)$, forestry - 117.9 billion soums. soums $(101.6 \%)$, and fisheries - 479.6 billion soums. soums $(126.8 \%)$.

In this regard, the Decree of the President of the Republic of Uzbekistan "On Strategy of Action for Further Development of the Republic of Uzbekistan" [1] states:

- Deepening of structural changes and continuous development of agricultural production, further strengthening of food security of the country, expansion of production of ecologically clean products, considerable increase of export potential of the agrarian sector;

- Reduce cotton and cereal grains, further improve the area of crops, placement of potatoes, vegetables, food and oil crops, as well as new intensive gardens and vineyards;

- Priority tasks for expanding research activities to create and introduce new varieties of agricultural crops and high-productivity, resistant to disease and pest, adapted to local climatic and ecological conditions are of great importance.

Use of new modern intensive agro technologies in food security, soil fertility improvement through land-reclamation and water management, livestock development, and supply of agriculture with new, modern, high-efficiency and economical equipment.

Today, the world's population witnesses a 7.6 billion increase in the food supply to the world's population at 7.6 billion people, 8.6 billion in 2030 , 9.8 billion in 2050 and 11.2 billion in 2100 . The introduction of new agro technologies in agriculture, improvement of selection and seeds, and use of "Smart technologies" in the development of agricultural crops and pest control are becoming a pressing issue today. [12]

According to the global forecast for 2023, automated agriculture (agriculture, animal husbandry, fishing and other monitoring) systems and GPS technologies (automated data storage systems that read or write data through unmanned aerial vehicles, sensors, radio signals, ) is expected to be popular. [14]

This, in turn, contributes to a considerable increase in the efficiency of screening, data management, use of pesticides and fertilizers, better control over the needs of individual animals, their nutrition, and the prevention and health of neuronal technologies in agriculture, the key to the future.

In line with the Decree of the President of the Republic of Uzbekistan "On the Establishment of the Ministry of Innovative Development," the introduction of modern forms of agricultural production, based on the concept of "smart agriculture", which primarily envisages the rational use of existing land, water and other natural resources in the field of innovation in agriculture implementation, maximum automation of agricultural production in the agrarian sector, significant increase of productivity and improvement of financial indicators, as well as the promotion of innovative ideas, developments and technologies that will ensure the country's food security are identified as the main activities of the ministry. [11]

Establishment of such a task implies the development of new techniques and technologies in the development of this sphere and conducting scientific research in practice. In this regard, the work in this area has already begun in many developed countries. Goldman Sachs Group analysts say many countries have been actively promoting their agriculture by switching from "analog" to "smart." According to their predictions, with the introduction of new technological solutions, by 2050 , it is possible to achieve a 70 per cent increase in farming worldwide. It's almost 800 billion. This is a $\$ 5,000$ additional product. [13]

Nowadays, in developed foreign countries, the fact that the agricultural machinery is produced with IoT (Internet of Things Internet) sensors and webinterfaces means that the value of these cars is not that everyone can not use such machines. For example, in the European Union, 80 percent of agricultural machinery is sold by navigation systems, but most likely, almost 30 percent of them do not have access to the network and the predominance of smaller family farms with adequate techniques are more expensive than ordinary cars.

Making use of the opportunities created in our country, we make a great contribution to the creation of these technologies and technologies, the prosperity of our country, the development of the agricultural economy. In our view, it is desirable to focus on four areas of innovation development and implementation in agriculture (Figure 1). 


\begin{tabular}{|c|c|c|c|c|c|c|}
\hline \multirow{4}{*}{ Impact Factor: } & ISRA (India) & $=3.117$ & SIS (USA) & $=0.912$ & ICV (Poland) & $=6.630$ \\
\hline & ISI (Dubai, UAE & $=0.829$ & РИНЦ (Russia & $=0.156$ & PIF (India) & $=1.940$ \\
\hline & GIF (Australia) & $=0.564$ & ESJI (KZ) & $=8.716$ & IBI (India) & $=4.260$ \\
\hline & JIF & $=1.500$ & SJIF (Morocco & $=5.667$ & OAJI (USA) & $=0.350$ \\
\hline
\end{tabular}

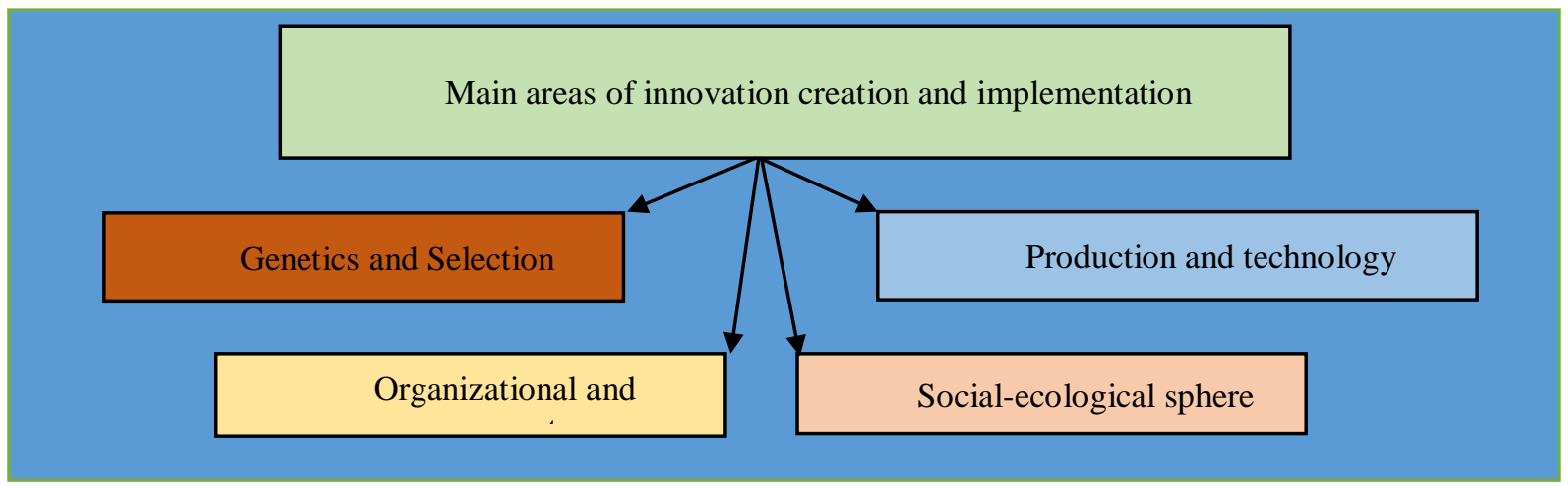

Source: author`s elaboration.

Fig. 1. Main areas of innovation creation and implementation.

As can be deduced from the figure 1, first of all, genetics and selection are distinguished by the product's competitiveness, quality, and, in particular, flexibility in any other product, of which the product is grown. Provides innovation in production and technology, cost savings, security of manufactured products, and cost savings.

Innovation in organizational and governance enhances modern management, increased employee timeframe and motivation for work. Innovation in the socio-environmental sphere, improving the wellbeing of the population, health and life expectancy are important in maintaining environmental cleanness.

From the research, it should be emphasized that in the development of "Smart Farming" at the same time in our country, first of all, the state of the controlled objects through dozens of square kilometers of radiocommunications - mainly, soil moisture, temperature, vegetation health, fuel reserve and other important parameters the use of sensors and sensors that provide continuous data transmission, transferring the data from neuronal networks and fixing the problem solution quickly, according to the text (Figure 2).

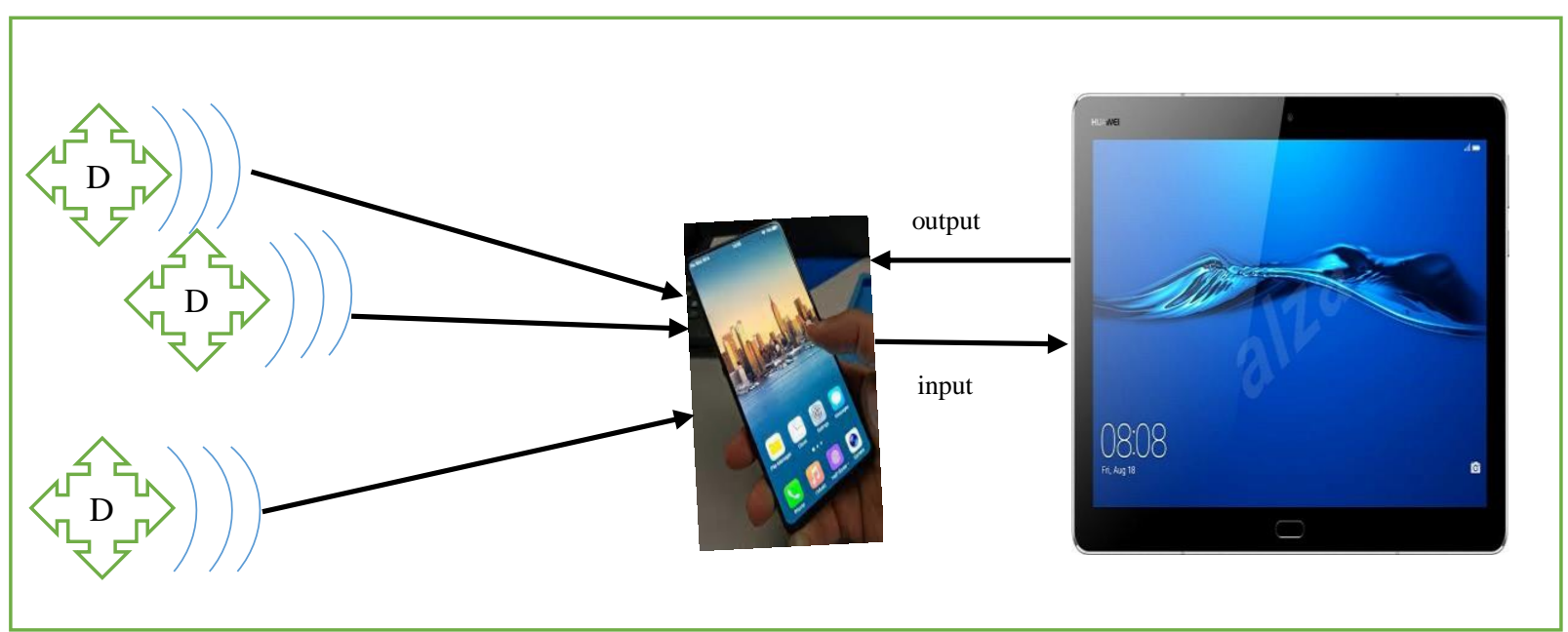

Source: author`s elaboration.

Fig. 2. The structure of the work done in "Smart Farming".

Figure 2 shows the data from the remote sensors, which comes to the cellular phone when it is integrated into computer technology into a neural network system and then analyzed and transmitted back to the mobile phone. Based on the information received, the farmer provides a quick solution to his / her decision. Of course, a decisive neural networking program must be established for this purpose.

Therefore, the use of neural network systems in socio-economic processes is widening. From the point of view of increasing the quality and quantity of crops in agriculture depends on many factors, and the most experienced expert cannot analyze them perfectly and do not have the right decisions. That is why the introduction of modern technology in this direction is a key issue today.

This electronic device system can be used to effectively manage other livestock and fisheries, ie to control the location and weather changes of the livestock, to determine the time of pregnancy, breastfeeding and disease symptoms of the animals. 


\begin{tabular}{|c|c|c|c|c|c|c|}
\hline \multirow{4}{*}{ Impact Factor: } & ISRA (India) & $=3.117$ & SIS (USA) & $=0.912$ & ICV (Poland) & $=6.630$ \\
\hline & ISI (Dubai, UAE & $=0.829$ & РИНЦ (Russia & $=0.156$ & PIF (India) & $=1.940$ \\
\hline & GIF (Australia) & $=0.564$ & ESJI (KZ) & $=8.716$ & IBI (India) & $=4.260$ \\
\hline & JIF & $=1.500$ & SJIF (Morocco & $=5.667$ & OAJI (USA) & $=0.350$ \\
\hline
\end{tabular}

\section{Conclusion}

In other words, the developed ideas and proposals will help to increase productivity and productivity by shaping a neurotechnology system in Uzbekistan effectively managing agricultural activities. At the same time, it will serve to economically justify the development and reproduction of competitive products in domestic and foreign markets by diversifying and diversifying the attractiveness of agricultural products. As a result, the development of this sector will have the potential to expand the scope of additional production and will have a positive impact on the prospects for increasing exports.

\section{References:}

1. (2017). The Decree of the President of the Republic of Uzbekistan Sh.Mirziyoev "On the Strategy for the Further Development of the Republic of Uzbekistan" dated February 7, 2017, N UP-4947. // The phrase "People's Word" 28 February (28), February 8, 2017.

2. Abduganiev, A. (2002). Development of farms and ways to improve their productivity. "Agriculture of Uzbekistan" magazine, No. 4.

3. Hasanov, S. T. (2017). Increasing the efficiency of using land and water resources in agriculture. 08.00.04- The dissertation for the degree of Doctor of Philosophy (DSc) on the specialty "Agricultural Economics" in 2017.

4. Ahmedov, A. K. (2018). Increasing the efficiency of using water-saving and innovative technologies in agriculture. 08.00.04- The dissertation for the degree of Doctor of Philosophy $(\mathrm{PhD})$ on the specialty "Agricultural Economics" in 2018.

5. Hakimov, R., et al. (2004). Agro-industrial complex. T.: Writers Union of Uzbekistan Literary Foundation.

6. Barsky, B. (2004). Neural networks: recognition, control, decision making. (p.176). M.: Finance and Statistics. (Applied information technology).
7. Kurnikov, D. S., \& Petrov, S. A. (2017). Using Neural Networks in Economics. Technical and Computer Science | Juvenis Scientia, № 6.

8. Yuldoshev, N., Tursunov, B., \& Qozoqov, S. (2018). Use of artificial intelligence methods in operational planning of textile production. Journal of Process Management. New Technologies, 6(2), 41-51.

9. Tursunov, B. (2017). Ways of increasing the efficiency of usage the production capacity of textile enterprises. Bulletin of science and practice, (8), 232-242.

10. Yezhov, A. A., \& Shumsky, S. A. (1998). Nerocomputing and its application in economics and business. (p.224). Moscow: MEPI.

11. (2017). To declare invalid the Presidential decree of the Republic of Uzbekistan from November 29, 2017 of N UP-5264 "About creation of the Ministry of innovative development of the Republic of Uzbekistan". Retrieved 2019, from http://lex.uz

12. (n.d.). "Polevoy" Internet veshchey. Retrieved 2019, from https://habr.com

13. (n.d.). Retrieved 2019, from https://www.un.org

14. (n.d.). Retrieved 2019, from https://www.crdc.com. 